\title{
Effect of Integrated Nutrient Management Practice on Growth and Yield of Foxtail Milllet (Setaria italica L.) in Black Soil
}

\author{
Raviraja $^{1 *}$, S. R. Balanagoudar ${ }^{1}$, M. V. Ravi ${ }^{1}$, \\ S. N. Bhat $^{1}$ and G. S. Yadahalli ${ }^{2}$ \\ ${ }^{1}$ Department of Soil Science and Agricultural Chemistry, ${ }^{2}$ Department of Agronomy, \\ University of Agricultural Sciences, Raichur - 584104, Karnataka, India \\ *Corresponding author
}

\begin{tabular}{l} 
K e y w o r d s \\
$\begin{array}{l}\text { Foxtail millet, } \\
\text { Growth and yield } \\
\text { attributes, Grain } \\
\text { yield, Stover yield }\end{array}$ \\
Article Info \\
$\begin{array}{l}\text { Accepted: } \\
\text { 15 February } 2020 \\
\text { Available Online: } \\
\text { 10 March } 2020\end{array}$ \\
\hline
\end{tabular}

\section{A B S T R A C T}

A field experiment was conducted at Main Agricultural Research Station, Raichur, Karnataka, during kharif 2018-2019 to study the "Effect of integrated nutrient management practice on growth and yield of foxtail milllet (Setaria italica L.) in black soil" to evaluate and analysis of foxtail millet through nutrient management practices to achieve higher growth and yield parameters. Total dry matter production $(3.12,13.15$ and $30.75 \mathrm{~g} \mathrm{plant}^{-1}$ at 30, 60 and at harvest, respectively), leaf area (40.90, 79.01 and 22.99 $\mathrm{dm}^{2}$ plant $^{-1}$ at 30, 60 DAS and at harvest, respectively), leaf area index $(0.17,0.30$ and 0.10 $\mathrm{dm}^{2}$ plant $^{-1}$ at 30,60 DAS and at harvest, respectively), number of tillers (4.30 plant ${ }^{-1}$ ) and plant height $(31.03,112.10$ and $141.80 \mathrm{~cm}$ at 30, 60 DAS and at harvest, respectively), were significantly superior with application of RPP $\left(\mathrm{RDF}+2.5 \mathrm{t} \mathrm{ha}^{-1}\right.$ Vermicompost + Bio-fertilizer) + Spray of 19:19:19 at 15, 30 and 45 DAS $\left(\mathrm{T}_{11}\right)$ as compared to $\left(\mathrm{T}_{1}\right)$ absolute control. Adoption of RPP (RDF + $2.5 \mathrm{t} \mathrm{ha}^{-1}$ Vermicompost + Bio-fertilizer) + Spray of 19:19:19 at 15, 30 and 45 DAS $\left(\mathrm{T}_{11}\right)$ was significantly higher grain yield and straw yield (25.95 and $\left.46.70 \mathrm{q} \mathrm{ha}^{-1}\right)$, however, lower grain yield and straw yield (8.53 and $15.51 \mathrm{q} \mathrm{ha}^{-1}$ ) was obtained in $\left(\mathrm{T}_{1}\right)$ absolute control. Similarly RPP (RDF $+2.5 \mathrm{t} \mathrm{ha}^{-1}$ Vermicompost + Bio-fertilizer) + Spray of 19:19:19 at 15, 30 and 45 DAS $\left(\mathrm{T}_{11}\right)$ significantly higher weight of ear head $\left(10.65 \mathrm{~g} \mathrm{plant}^{-1}\right)$, length of ear head $(23 \mathrm{~cm})$ and number of ear head (4.63 plant $\left.^{-1}\right)$ as compared to lower weight of ear head (5.53 $\left.\mathrm{g} \mathrm{plant}^{-1}\right)$, length of ear head $(10.82 \mathrm{~cm})$ and number of ear head $\left(2.27\right.$ plant $\left.^{-1}\right)$ was noticed in $\left(\mathrm{T}_{1}\right)$ absolute control.

\section{Introduction}

The term "small millet" refers to a group of small seeded annual cereal crops and foxtail or Italian millet (Setaria italica L.) locally called Navane (kakun) is one of them. India is the largest producer of many kinds of millets (foxtail millet, finger millet, barnyard millet etc.), which are often referred to as coarse cereals. Foxtail millet is consumed by the rural or tribal population of warmer region in India (Andhra Pradesh, Karnataka, Tamil 
Nadu, Uttar Pradesh and Southern Rajasthan). Foxtail millet grain is the staple diet and nutritious source of vitamins, minerals, protein and carbohydrates, while its Stover is a valuable livestock feed. Minor millet have the potential to provide food and nutrition security as well as to ensure sustainability for poor farmers and fragile ecosystem.

Minor millet grain contain high proportion of carbohydrates and protein which is in the form of non-starchy polysaccharide and dietary fibre, help in prevention of constipation, lowering of cholesterol and slow release of glucose to the blood stream during digestion. It is also rich in important vitamins viz., thiamine, riboflavin, folic acid and niacin. It is of interest to note that lower incidence of cardiovascular disease; duodenal ulcer and hyperglycaemia (diabetes) are reported among regular millet consumers. Foxtail millet grain contains 12.3 per cent protein, 4.7 per cent fat, 60.6 per cent carbohydrate, 3.2 per cent ash and mineral nutrients (Singh et al., 2003). Foxtail millet is particularly low in phytic acid and rich in iron and calcium (Sampat et al., 1990). Its grain are cooked like, rice and ground for making chapatis. The crop is also good for fodder purpose due to the thin stem; it is liked by cattle (Singh et al., 2003).

Organic manures in agriculture add organic and mineral matter. Organic systems rely on management of organic matter to enhance the soil fertility and productivity. Organic matter has an over effect on almost all soil properties. Organic matter most precious component is also considered as store house of many nutrients.

For mineralization of organic matter, soil fauna and microorganisms are indispensible. Soil harbours a dynamic microbial population, arthropods and others (soil biota). The living phase of soil is greatly stimulated by organic manure addition which serves as a food (carbon) and energy source for soil life. Both soil and enzyme systems are associated with organic manure management which carried out a wide range of processes that are important for soil health and fertility. The proper management of these in a farming unit makes it possible to increase the efficiency of use of soil and added nutrients (Ramesh, 2007).

\section{Materials and Methods}

The field experiment was conducted at Main Agricultural Research Station, Raichur, the experiment was laid out in RCBD and comprised of 12 treatments for study viz., $\mathrm{T}_{1}$ : Absolute control, $\mathrm{T}_{2}$ : RDF (30:15:15 $\left.\mathrm{kg} \mathrm{ha}^{-1}\right)$, $\mathrm{T}_{3}$ :FYM $6 \mathrm{t} \mathrm{ha}^{-1}, \mathrm{~T}_{4}$ : Vermicompost $2.5 \mathrm{t} \mathrm{ha}^{-1}$, $\mathrm{T}_{5}: \mathrm{RPP}\left(\mathrm{RDF}+6 \mathrm{t} \mathrm{ha}^{-1}\right.$ FYM + Biofertilizer), $\mathrm{T}_{6}: \operatorname{RPP}\left(\mathrm{RDF}+2.5 \mathrm{t} \mathrm{ha}^{-1}\right.$ Vermicompost + Bio-fertilizer), $\mathrm{T}_{7}: \mathrm{RDF}+$ Foliar Spray of 19:19:19 at 15, 30 and 45 DAS, T: FYM $6 \mathrm{t} \mathrm{ha}^{-1}+$ Foliar Spray of 19:19:19 at 15, 30 and 45 DAS, $\mathrm{T}_{9}$ : Vermicompost $2.5 \mathrm{t} \mathrm{ha}^{-1}+$ Foliar Spray of 19:19:19 at 15, 30 and 45 DAS, T 10 : RPP $\left(\mathrm{RDF}+6 \mathrm{t} \mathrm{ha}^{-1} \mathrm{FYM}+\right.$ Bio-fertilizer $)+$ Foliar Spray of 19:19:19 at 15, 30 and 45 DAS and $\mathrm{T}_{11}$ : RPP (RDF + $2.5 \mathrm{t} \mathrm{ha}^{-1}$ Vermicompost + Bio-fertilizer) + Foliar Spray of 19:19:19 at 15, 30 and 45 DAS. The soils of the experimental site belong to medium deep black soil and clay texture, neutral in soil reaction (7.6) and low in electrical conductivity $\left(0.22 \mathrm{dSm}^{-1}\right)$.

The organic carbon content was $4.9 \mathrm{~g} \mathrm{~kg}^{-1}$ and available $\mathrm{N} \quad\left(265.8 \quad \mathrm{~kg}^{-1} \mathrm{ha}^{-1}\right)$, available phosphorus (27.40 $\mathrm{kg} \mathrm{P}_{2} \mathrm{O}_{5} \mathrm{ha}^{-1}$ ) and available potassium (325.6 $\mathrm{kg} \mathrm{K}_{2} \mathrm{O} \mathrm{ha}{ }^{-1}$ ), exchangeable calcium and magnesium (25.18 and $6.2 \mathrm{C} \mathrm{mol}$ $\left(\mathrm{p}^{+}\right) \mathrm{kg}$ ), available sulphur (35.9 $\left.\mathrm{mg} \mathrm{kg}^{-1}\right)$, DTPA extractable zinc $\left(0.68 \mathrm{mg} \mathrm{kg}^{-1}\right)$, DTPA extractable iron $\left(5.25 \mathrm{mg} \mathrm{kg} \mathrm{kg}^{-1}\right)$, DTPA extractable manganese $\left(15.4 \mathrm{mg} \mathrm{kg}^{-1}\right)$ and 
DTPA extractable copper (1.08 $\left.\mathrm{mg} \mathrm{kg}^{-1}\right)$. The mean monthly meteorological data of rainfall, temperature and relative humidity during the period of experimentation (2018-19) recorded at the meteorological observatory of the MARS, Raichur.

\section{Results and Discussion}

The data pertaining to growth parameters like, plant height, leaf area, leaf area index and total dry matter production of foxtail millet were significantly differed due to different nutrient management practices are depicted in Table 1.

Growth parameters like, plant height, leaf area, leaf area index and total dry matter production of $114.87 \mathrm{~cm}, 22.99 \mathrm{dm}^{2}$ plant $^{-1}$, $0.10 \mathrm{dm}^{2}$ plant $^{-1}$ and $30.75 \mathrm{~g} \mathrm{plant}^{-1}$ at harvest, respectively, were significantly higher with application of RPP (RDF $+2.5 \mathrm{t} \mathrm{ha}^{-1}$ Vermicompost + Bio-fertilizer) + Spray of 19:19:19 at 15, 30 and 45 DAS $\left(\mathrm{T}_{11}\right)$. But it was on par with treatment $\mathrm{T}_{10}$ : RPP $(\mathrm{RDF}+6 \mathrm{t}$ ha $^{-1}$ FYM + Bio-fertilizer) + Spray of 19:19:19 at 15, 30 and 45 DAS. However, lower growth parameter was observed in absolute control $\left(\mathrm{T}_{1}\right)$.

The high plant height, leaf area per plant and leaf area index were significantly higher which was due to main contribution of photosynthetic activity which resulted in higher dry matter production and also higher dry matter accumulation resulted due to combination of organic or inorganic sources, contributed to accelerate the enzymatic activity and auxin metabolism in plants. Also, it will improve the cell division and cell enlargement due to increased photosynthetic rate subsequently increasing the total dry matter production. Similar results were obtained by Govindappa (2003) and Guggari and Kalaghatagi (2001) in pearl millet.
The data pertaining to yield and yield attributes like, number of ear head, length of ear head, weight of ear head grain weight, 1000 grain weight, number of tillers grain yield, stover yield and harvest index of foxtail millet were significantly differed due to different nutrient management practices are presented in Table $2,3 \& 4$.

Grain yield and stover yield of foxtail millet differed significantly higher through integrated nutrient management practices. The application with RPP (RDF + $2.5 \mathrm{t} \mathrm{ha}^{-1}$ Vermicompost + Bio-fertilizer) + Spray of 19:19:19 at 15, 30 and 45 DAS $\left(\mathrm{T}_{11}\right)$ significantly higher grain yield and straw yield (25.95 and $\left.46.70 \mathrm{q} \mathrm{ha}^{-1}\right)$, but it was on par with treatment $\mathrm{T}_{10}$ : RPP $\left(\mathrm{RDF}+6 \mathrm{t} \mathrm{ha}^{-1}\right.$ FYM + Bio-fertilizer) + Spray of 19:19:19 at 15, 30 and 45 DAS (22.91 and $43.80 \mathrm{q} \mathrm{ha}^{-1}$ ), however, lower grain yield and straw yield was obtained in $\left(\mathrm{T}_{1}\right)$ absolute control (8.53 and $15.51 \mathrm{q} \mathrm{ha}^{-1}$ ).

The variation in the yield was due to the variation in the yield components viz., weight of ear head, length of ear head, number of ear heads and test weight. The application of RPP (RDF + $2.5 \mathrm{t} \mathrm{ha}^{-1}$ Vermicompost + Biofertilizer) + Spray of 19:19:19 at 15, 30 and 45 DAS $\left(T_{11}\right)$ was significantly higher weight of ear head (10.65 $\left.\mathrm{g} \mathrm{plant}^{-1}\right)$, length of ear head $(23 \mathrm{~cm})$ and number of ear head $(4.63$ plant $\left.^{-1}\right)$, but it was on par with treatment $T_{10}$ : RPP (RDF + $6 \mathrm{t} \mathrm{ha}^{-1}$ FYM + Bio-fertilizer) + Spray of 19:19:19 at 15, 30 and 45 DAS were significantly higher weight of ear head (10.23 $\left.\mathrm{g} \mathrm{plant}^{-1}\right)$, length of ear head $(21.83 \mathrm{~cm})$ and number of ear head (4.30 plant $\left.^{-1}\right)$.

However, lower weight of ear head (5.53 g plant $\left.^{-1}\right)$, length of ear head $(10.82 \mathrm{~cm})$ and number of ear head (2.27 plant $\left.^{-1}\right)$ was obtained in $\left(\mathrm{T}_{1}\right)$ absolute control. 
Table.1 Growth parameters of foxtail millet at harvest as influenced by integrated nutrient management practices

\begin{tabular}{|c|c|c|c|c|}
\hline Treatments & $\begin{array}{l}\text { Plant height } \\
\quad(\mathrm{cm})\end{array}$ & $\begin{array}{l}\text { Leaf area } \\
\left(\mathrm{cm}^{-2}\right)\end{array}$ & $\begin{array}{l}\text { Leaf area } \\
\text { index }\end{array}$ & 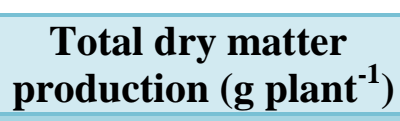 \\
\hline & \multicolumn{4}{|c|}{ At harvest } \\
\hline $\mathrm{T}_{1}$ : Absolute control & 114.87 & 14.86 & 0.06 & 17.86 \\
\hline $\mathrm{T}_{2}:$ RDF (30:15:15 $\left.\mathrm{kg} \mathrm{ha}^{-1}\right)$ & 126.37 & 18.73 & 0.07 & 23.45 \\
\hline $\mathrm{T}_{3}:$ FYM $6 \mathrm{t} \mathrm{ha}^{-1}$ & 119.50 & 17.87 & 0.06 & 20.02 \\
\hline $\mathrm{T}_{4}:$ Vermicompost $2.5 \mathrm{t} \mathrm{ha}^{-1}$ & 124.10 & 18.12 & 0.07 & 21.67 \\
\hline$T_{5}:$ RPP (RDF + 6 t ha $^{-1}$ FYM + Bio-fertilizer $)$ & 130.60 & 20.86 & 0.08 & 24.75 \\
\hline $\mathrm{T}_{6}:$ RPP $\left(\mathrm{RDF}+2.5 \mathrm{t} \mathrm{ha}^{-1}\right.$ Vermicompost + Bio-fertilizer $)$ & 133.87 & 21.20 & 0.08 & 27.05 \\
\hline$T_{7}:$ RDF + Foliar Spray of 19:19:19 at 15,30 and 45 DAS & 127.33 & 19.18 & 0.07 & 25.81 \\
\hline $\begin{array}{l}\text { T}_{8}: \text { FYM } 6 \mathrm{tha}^{-1}+\text { Foliar Spray of } 19: 19: 19 \text { at } 15,30 \text { and } \\
45 \text { DAS }\end{array}$ & 129.00 & 19.23 & 0.07 & 26.79 \\
\hline $\begin{array}{l}\text { T9 }_{9} \text { : Vermicompost } 2.5 \mathrm{t} \mathrm{ha}^{-1}+\text { Foliar Spray of 19:19:19 at } \\
15,30 \text { and } 45 \text { DAS }\end{array}$ & 131.83 & 20.89 & 0.08 & 26.31 \\
\hline $\begin{array}{l}\left.\text { T }_{10}: \text { RPP (RDF + } 6 \mathrm{t} \mathrm{ha}^{-1} \text { FYM + Bio-fertilizer }\right)+ \text { Foliar } \\
\text { Spray of 19:19:19 at 15, } 30 \text { and } 45 \text { DAS }\end{array}$ & 138.47 & 22.13 & 0.09 & 28.10 \\
\hline $\begin{aligned} \mathrm{T}_{11} & : \text { RPP }\left(\mathrm{RDF}+2.5 \mathrm{t} \mathrm{ha}^{-1} \text { Vermicompost + Bio-fertilizer }\right) \\
& + \text { Foliar Spray of 19:19:19 at 15, } 30 \text { and } 45 \text { DAS }\end{aligned}$ & 141.80 & 22.99 & 0.10 & 30.75 \\
\hline S. Em \pm & 1.37 & 0.75 & 0.03 & 0.92 \\
\hline CD at $5 \%$ & 3.94 & 2.15 & NS & 2.67 \\
\hline
\end{tabular}


Table.2 Number of ear head, length of ear head and weight of ear head of foxtail millet as influenced by integrated nutrient management practices

\begin{tabular}{|c|c|c|c|}
\hline Treatments & $\begin{array}{l}\text { No of ear head } \\
\quad\left(\text { Plant }^{-1}\right)\end{array}$ & $\begin{array}{l}\text { Length of ear head } \\
\qquad(\mathrm{cm})\end{array}$ & $\begin{array}{l}\text { Weight of ear head } \\
\quad\left(\text { g plant }^{-1}\right)\end{array}$ \\
\hline $\mathbf{T}_{1}:$ Absolute control & 2.27 & 10.82 & 5.53 \\
\hline$T_{2}:$ RDF (30:15:15 kg ha $\left.{ }^{-1}\right)$ & 3.23 & 16.41 & 7.26 \\
\hline T $_{3}:$ FYM 6 t ha $^{-1}$ & 2.57 & 13.65 & 6.52 \\
\hline $\mathrm{T}_{4}:$ Vermicompost $2.5 \mathrm{t} \mathrm{ha}^{-1}$ & 2.93 & 14.76 & 7.06 \\
\hline$T_{5}:$ RPP (RDF + 6 t ha $^{-1}$ FYM + Bio-fertilizer) & 3.60 & 19.25 & 8.09 \\
\hline $\mathrm{T}_{6}: \mathrm{RPP}\left(\mathrm{RDF}+2.5 \mathrm{t} \mathrm{ha}^{-1}\right.$ Vermicompost + Bio-fertilizer $)$ & 3.80 & 20.03 & 8.58 \\
\hline$T_{7}:$ RDF+ Foliar Spray of 19:19:19 at 15,30 and 45 DAS & 3.40 & 16.61 & 7.28 \\
\hline T $_{8}:$ FYM $6 \mathrm{t} \mathrm{ha}^{-1}+$ Foliar Spray of 19:19:19 at 15, 30 and 45 DAS $^{1}$ & 3.53 & 17.47 & 8.07 \\
\hline $\begin{array}{l}\text { T}_{9}: \text { Vermicompost } 2.5 \mathrm{t} \mathrm{ha}^{-1}+\text { Foliar Spray of 19:19:19 at } 15,30 \text { and } \\
45 \text { DAS }\end{array}$ & 3.73 & 19.33 & 8.30 \\
\hline $\begin{array}{l}T_{10}: \text { RPP }\left(\text { RDF }+6 \mathrm{tha}^{-1} \text { FYM + Bio-fertilizer }\right)+\text { Foliar Spray of } \\
\text { 19:19:19 at 15, } 30 \text { and } 45 \text { DAS }\end{array}$ & 4.30 & 21.83 & 10.23 \\
\hline $\begin{array}{l}T_{11}: \text { RPP }\left(\text { RDF }+2.5 \mathrm{t} \mathrm{ha}^{-1} \text { Vermicompost }+ \text { Bio-fertilizer }\right)+\text { Foliar } \\
\text { Spray of 19:19:19 at 15, } 30 \text { and } 45 \text { DAS }\end{array}$ & 4.63 & 23.07 & 10.65 \\
\hline S. Em \pm & 0.13 & 1.17 & 0.17 \\
\hline CD at $5 \%$ & 0.35 & 3.44 & 0.49 \\
\hline
\end{tabular}


Table.3 Grain weight, 1000 grain weight and number of tillers at harvest of foxtail millet as influenced by integrated nutrient management practices

\begin{tabular}{|c|c|c|c|}
\hline Treatments & $\begin{array}{l}\text { Grain weight } \\
\left(\text { g plant }^{-1}\right)\end{array}$ & $\begin{array}{l}1000 \text { grain weight } \\
\text { (g) }\end{array}$ & $\begin{array}{l}\text { Number of tillers } \\
\left.\text { (plant }^{-1}\right)\end{array}$ \\
\hline$T_{1}:$ Absolute control & 5.98 & 3.83 & 2.27 \\
\hline $\mathrm{T}_{2}: \operatorname{RDF}\left(30: 15: 15 \mathrm{~kg} \mathrm{ha}^{-1}\right)$ & 8.75 & 4.46 & 3.23 \\
\hline $\mathrm{T}_{3}:$ FYM $6 \mathrm{t} \mathrm{ha}^{-1}$ & 8.07 & 4.26 & 2.57 \\
\hline $\mathrm{T}_{4}:$ Vermicompost $2.5 \mathrm{t} \mathrm{ha}^{-1}$ & 8.43 & 4.40 & 2.93 \\
\hline$T_{5}:$ RPP (RDF + 6 t ha $^{-1}$ FYM + Bio-fertilizer $)$ & 9.03 & 4.55 & 3.60 \\
\hline$T_{6}: \operatorname{RPP}\left(\mathrm{RDF}+2.5 \mathrm{t} \mathrm{ha}^{-1}\right.$ Vermicompost + Bio-fertilizer $)$ & 9.61 & 5.13 & 3.80 \\
\hline$T_{7}:$ RDF+ Foliar Spray of 19:19:19 at 15, 30 and 45 DAS & 8.95 & 4.48 & 3.40 \\
\hline T $_{8}:$ FYM $\mathrm{t} \mathrm{ha}^{-1}+$ Foliar Spray of 19:19:19 at 15, 30 and 45 DAS $^{1}$ & 9.03 & 4.52 & 3.53 \\
\hline $\mathrm{T}_{9}:$ Vermicompost $2.5 \mathrm{t} \mathrm{ha}^{-1}+$ Foliar Spray of $19: 19: 19$ at 15,30 and 45 DAS & 9.15 & 4.94 & 3.73 \\
\hline $\begin{array}{l}\text { T }_{10}: \text { RPP }\left(\text { RDF }+6 \mathrm{t} \mathrm{ha}^{-1} \text { FYM + Bio-fertilizer }\right)+\text { Foliar Spray of 19:19:19 at } \\
\text { 15, 30 and } 45 \text { DAS }\end{array}$ & 11.80 & 5.35 & 4.30 \\
\hline $\begin{array}{l}T_{11}: \text { RPP }\left(\text { RDF }+2.5 \mathrm{t} \mathrm{ha}^{-1} \text { Vermicompost + Bio-fertilizer }\right)+\text { Foliar Spray of } \\
\text { 19:19:19 at 15, } 30 \text { and } 45 \text { DAS }\end{array}$ & 12.19 & 5.73 & 4.63 \\
\hline S.Em \pm & 0.17 & 0.36 & 0.38 \\
\hline CD at $5 \%$ & 0.49 & 1.04 & 1.12 \\
\hline
\end{tabular}


Table.4 Grain yield, stover yield and harvest index of foxtail millet as influenced by nutrient management practices

\begin{tabular}{|c|c|c|c|}
\hline Treatments & $\begin{array}{l}\text { Grain yield } \\
\left.\text { (kg ha }^{-1}\right)\end{array}$ & $\begin{array}{l}\text { Stover } \\
\text { yield } \\
\left(\mathrm{kg} \mathrm{ha}^{-1}\right)\end{array}$ & $\begin{array}{l}\text { Harvest } \\
\text { index } \\
(\%)\end{array}$ \\
\hline $\mathrm{T}_{1}$ : Absolute control & 853 & 2230 & 27.7 \\
\hline$T_{2}: \operatorname{RDF}\left(30: 15: 15 \mathrm{~kg} \mathrm{ha}^{-1}\right)$ & 1448 & 3534 & 29.1 \\
\hline $\mathrm{T}_{3}:$ FYM $6 \mathrm{t} \mathrm{ha}^{-1}$ & 1285 & 2590 & 33.2 \\
\hline $\mathrm{T}_{4}:$ Vermicompost $2.5 \mathrm{t} \mathrm{ha}^{-1}$ & 1348 & 3469 & 28.0 \\
\hline $\mathrm{T}_{5}: \mathrm{RPP}\left(\mathrm{RDF}+6 \mathrm{t} \mathrm{ha}^{-1}\right.$ FYM + Bio-fertilizer $)$ & 1853 & 4530 & 29.0 \\
\hline $\mathrm{T}_{6}: \operatorname{RPP}\left(\mathrm{RDF}+2.5 \mathrm{t} \mathrm{ha}^{-1}\right.$ Vermicompost + Bio-fertilizer $)$ & 2024 & 5458 & 27.1 \\
\hline$T_{7}:$ RDF+ Foliar Spray of 19:19:19 at 15, 30 and 45 DAS & 1595 & 3668 & 30.3 \\
\hline T $_{8}:$ FYM $6 \mathrm{t} \mathrm{ha}^{-1}+$ Foliar Spray of 19:19:19 at 15, 30 and 45 DAS $^{1}$ & 1679 & 4261 & 28.3 \\
\hline $\mathrm{T}_{9}:$ Vermicompost $2.5 \mathrm{t} \mathrm{ha}^{-1}+$ Foliar Spray of $19: 19: 19$ at 15,30 and 45 DAS & 1838 & 4691 & 28.2 \\
\hline $\begin{array}{l}T_{10}: \text { RPP }\left(\text { RDF }+6 \text { tha }^{-1} \text { FYM+ Bio-fertilizer }\right)+\text { Foliar Spray of 19:19:19 at 15, } 30 \text { and } \\
\quad 45 \text { DAS }\end{array}$ & 2252 & 5775 & 28.1 \\
\hline $\begin{array}{l}T_{11}: \text { RPP }\left(\text { RDF }+2.5 \mathrm{t} \mathrm{ha}^{-1} \text { Vermicompost + Bio-fertilizer }\right)+\text { Foliar Spray of 19:19:19 at } \\
\quad 15,30 \text { and } 45 \text { DAS }\end{array}$ & 2414 & 6034 & 28.6 \\
\hline S.Em \pm & 95.19 & 128.60 & 0.01 \\
\hline CD at $5 \%$ & 280.80 & 379.36 & NS \\
\hline
\end{tabular}


This was mainly because of increasing in the levels and source of nutrients with organic manures significantly increased the straw yield of hybrid rice which might due to the integrated effect of $\mathrm{N}, \mathrm{P}$ and $\mathrm{K}$ levels and different sources of organic manures on $\mathrm{N}, \mathrm{P}$ and $\mathrm{K}$ availability and their uptake as well as grain and straw yield of hybrid rice. The supply of inorganic and organic manures increased the grain and straw yield of hybrid rice. The addition of organic manure might influence $\mathrm{N}, \mathrm{P}$ and $\mathrm{K}$ availability by maintaining good physical condition of soil for plant growth and yield. The increase in straw yield of hybrid rice with combined application of fertilizer and manure was reported by Rahman et al., (2005), Gupta et al., (2006) and Bajpai et al., (2006).

\section{References}

Bajpai, R. K., Chitale, S., Upadhyay, S. K. and Urkurkar, J. S., 2006, The long term studies on soil physico-chemical properties and productivity of ricewheat system as influenced by integrated nutrient management in Inceptisol of Chhattisgarh. J. Indian Soc. Soil Sci., 54: 24-29.

Govindappa, S., 2003, Influence of enriched bio-digester liquid manure on growth and yield of finger millet. The Bioscan, 9(2): 613-616.

Guggari, A. K. and Kalaghatagi, S. B., 2001, Effect of permanent manuring and nitrogen fertilization on pearl millet.
Karnataka J. Agric. Sci., 14(3): 601604.

Gupta, V., Sharma, R. S. and Vishvakarma, S. K., 2006, Long-term effect of integrated nutrient management on yield sustainability and soil fertility of rice (Oryza sativa L.) and wheat (Triticum aestivum L.) cropping system. Indian $J$. Agron., 51(12): 160-164.

Rahman, M. A., Chikushi, J., Saifizzaman, M. and Lauren, J. G., 2007, Rice straw mulching and nitrogen response of notill wheat following rice in Bangladesh. Field Crops Res. 91 (1): 71-81.

Ramesh, P., 2007, Organic Farming Research in Madhya Pradesh. Organic Farming in Rainfed Agriculture: Opportunities and Constraints, CRIDA, Hyderabad, pp. 12-20.

Sampth, T. V., Razvi, S. M., Singh, D. N. and Bondale, K.V, 1990, Small millet in Indian Agriculture. Small Millet in Global Agriculture, Oxford and IBH Publishing Co. Pvt. Ltd., New Delhi : 33-44.

Singh, C., Singh, P. and Singh, R. 2003, Impact of organic manures on foxtail millet [Setaria italica (L.) Beauv.] (In) Modern Techniques of Raising Field Crops: Oxford and IBH Publishing Co.Pvt. Ltd., New Delhi (Eds.-II), 187191.

Vinall, H.N. 1924. Foxtail millet its culture and utilization in the united state. USDA Farmer Bulletin: 793.

\section{How to cite this article:}

Raviraja, S. R. Balanagoudar, M. V. Ravi, S. N. Bhat and Yadahalli, G. S. 2020. Effect of Integrated Nutrient Management Practice on Growth and Yield of Foxtail Milllet (Setaria italica L.) in Black Soil. Int.J.Curr.Microbiol.App.Sci. 9(03): 2101-2108.

doi: https://doi.org/10.20546/ijcmas.2020.903.240 